\title{
On the Physical Death of Jesus Christ
}

\section{William D. Edwards, MD; Wesley J. Gabel, MDiv; Floyd E Hosmer, MS, AMI}

Reprinted from JAMA - The Journal of the American Medical Association

March 21, 1986, Volume 256

Copyright 1986, American Medical Association

From the Departments of Pathology (Dr. Edwards) and Medical Graphics (Mr. Hosmer), Mayo Clinic, Rochester, Minn.; and the Homestead United Methodist Church, Rochester, Minn., and the West Bethel United Methodist Church, Bethel, Minn. (Pastor Gabel).

Reprint requests to Department of Pathology, Mayo Clinic, Rochester, MN 55905 (Dr. Edwards)

\begin{abstract}
Jesus of Nazareth underwent Jewish and Roman trials, was flogged, and was sentenced to death by crucifixion. The scourging produced deep stripelike lacerations and appreciable blood loss, and it probably set the stage for hypovolemic shock, as evidenced by the fact that Jesus was too weakened to carry the crossbar (patibulum) to Golgotha. At the site of crucifixion, his wrists were nailed to the patibulum and, after the patibulum was lifted onto the upright post (stipes), his feet were nailed to the stipes. The major pathophysiologic effect of crucifixion was an interference with normal respirations. Accordingly death resulted primarily from hypovolemic shock and exhaustion asphyxia. Jesus' death was ensured by the thrust of a soldier's spear into his side. Modern medical interpretation of the historical evidence indicate that Jesus was dead when taken down from the cross.
\end{abstract}

\section{INTRODUCTION}

The life and teachings of Jesus of Nazareth have formed the basis for a major world religion (Christianity), have appreciably influenced the course of human history, and, by virtue of a compassionate attitude towards the sick, also have contributed to the development of modern medicine. The eminence of Jesus as a historical figure and the suffering and controversy associated with his death have stimulated us to investigate, in an interdisciplinary manner, the circumstances surrounding his crucifixion. Accordingly, it is our intent to present not a theological treatise but rather a medically and historically accurate account of the physical death of the one called Jesus Christ.

\section{SOURCES}

The source material concerning Christ's death comprises a body of literature and not a physical body or its skeletal remains. Accordingly, the credibility of any discussion of Jesus' death will be determined primarily by the credibility of one's sources. For this review, the source material includes the writings of ancient Christian and non-Christian authors, the writings of modern authors, and the Shroud of Turin. (1-40) Using the legal-historical method of scientific investigation, (27) scholars have established the reliability and accuracy of the ancient manuscripts. $(26,27,29,31)$

The most extensive and detailed descriptions of the life and death of Jesus are to be found in the New Testament gospels of Matthew, Mark, Luke, and John. (1) The other 23 books of the New Testament support but do not expand on the details recorded in the gospels. Contemporary Christian, Jewish, and Roman authors provide additional insight concerning the first-century Jewish and Roman legal systems and the details of scourging and crucifixion. (5) Seneca, Livy, Plutarch, and others refer to crucifixion practices in their works. $(8,28)$ Specifically, Jesus (or his crucifixion) is mentioned by the Roman historians Cornelius Tacitus, Pliny the Younger, and Suetonius, by non-Roman historians Thallus and Phlegon, by the satirist 
Lucian of Samosata, by the Jewish Talmud, and by the Jewish historian Flavius Josephus, although the authenticity of portions of the latter is problematic. (26)

The Shroud of Turin is considered by many to represent the actual burial cloth of Jesus, (22) and several publications concerning the medical aspects of his death draw conclusions from this assumption. $(5,11)$ The Shroud of Turin and recent archaeological findings provide valuable information concerning Roman crucifixion practices. (22-24) The interpretations of modern writers, based on a knowledge of science and medicine not available in the first century, may offer additional insight concerning the possible mechanisms of Jesus' death. $(2,17)$

When taken in concert, certain facts -- the extensive and early testimony of both Christian proponents and opponents, and their universal acceptance of Jesus as a true historical figure; the ethic of the gospel writers, and the shortness of the time interval between the events and the extant manuscripts; and the confirmation of the gospel accounts by historians and archaeological findings $(26,27)$-- ensure a reliable testimony from which a modern medical interpretation of Jesus' death may be made.

\section{GETHSEMANE}

After Jesus and his disciples had observed the Passover meal in an upper room in a home in southwest Jerusalem, they traveled to the Mount of Olives, northeast of the city. (Owing to various adjustments in the calendar, the years of Jesus' birth and death remain controversial. (29) However, it is likely that Jesus was born in either 4 or 6 BC and died in 30 AD. $(11,29)$ During the Passover observance in 30 AD, the last Supper would have been observed on Thursday, April 6 [Nisan 13], and Jesus would have been crucified on Friday, April 7 [Nisan 14]. (29) ) At nearby Gethsemane, Jesus, apparently knowing that the time of his

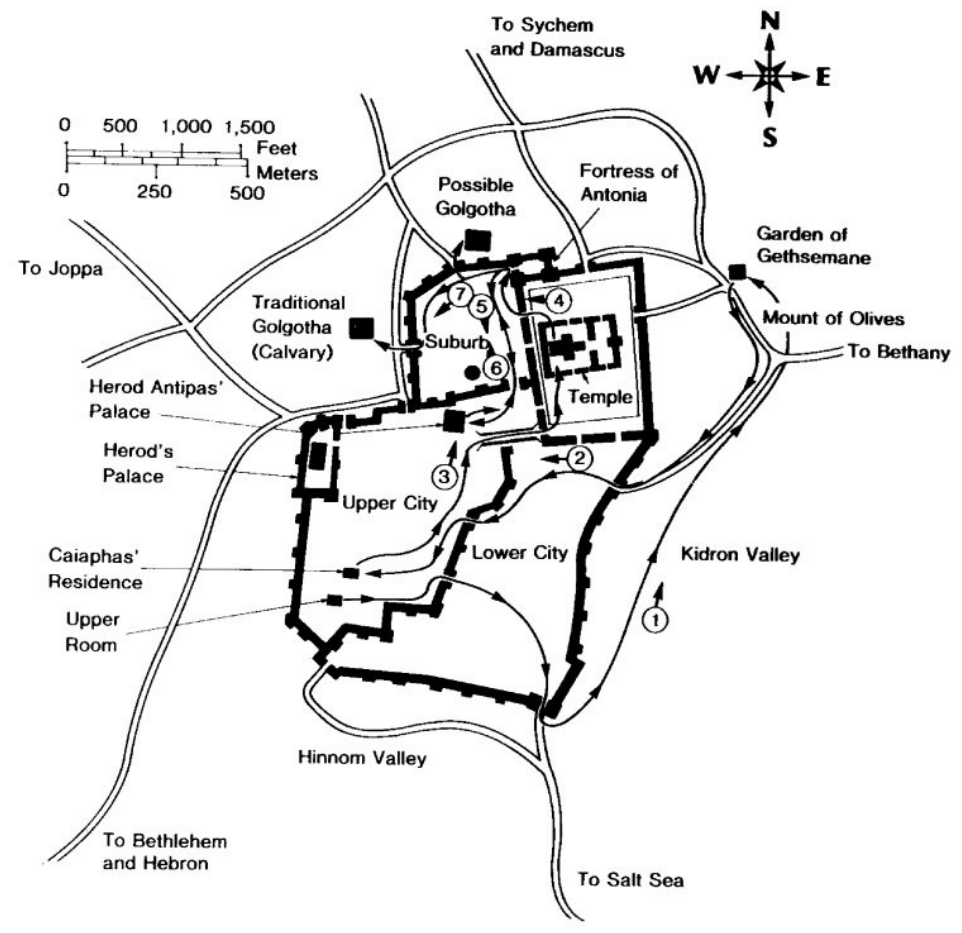
death was near, suffered great mental anguish, and, as described by the physician Luke, his sweat became like blood. (1)

Although this is a very rare phenomenon, bloody sweat (hematidrosis or hemohidrosis) may occur in highly emotional states or in persons with bleeding disorders. $(18,20)$ As a result of hemorrhage into the sweat glands, the skin becomes fragile and tender. $(2,11)$ Luke's descriptions supports the diagnosis of hematidrosis rather than eccrine chromidrosis (brown or yellow-green sweat) or stigmatization (blood oozing from the palms or elsewhere). $(18,21)$ Although some authors have suggested that hematidrosis produced hypovolemia, we agree with Bucklin (5) that Jesus' actual blood loss probably was minimal. However, in the cold night air, (1) it may have produced chills.

\section{TRIALS}

\section{Jewish Trials}

Soon after midnight, Jesus was arrested at Gethsemane by the temple officials and was taken first to Annas and then to Caiaphas, the Jewish high priest for that year. (1) Between 1 AM and daybreak, Jesus was tried before Caiaphas and the political Sanhedrin and was found guilty of blasphemy. (1) The guards then blindfolded Jesus, spat on him, and struck him in the face with their fists. (1) Soon after daybreak, presumably at the temple, Jesus was tried before the religious Sanhedrin (with the Pharisees and the 


\section{Roman Trials}

Since permission for an execution had to come from the governing Romans, (1) Jesus was taken early in the morning by the temple officials to the Praetorium of the Fortress of Antonia, the residence and governmental seat of Pontius Pilate, the procurator of Judea. However, Jesus was presented to Pilate not as a blasphemer but rather as a self-appointed king who would undermine the Roman authority. (1) Pilate made no charges against Jesus and sent him to Herod Antipas, the tetrarch of Judea. (1) Herod likewise made no official charges and then returned Jesus to Pilate. (1) Again, Pilate could find no basis for a legal charge against Jesus, but the people persistently demanded crucifixion. Pilate finally granted their demand and handed over Jesus to be flogged (scourged) and crucified. (McDowell (25) has reviewed the prevailing political, religious, and economic climates in Jerusalem at the time of Jesus' death, and Bucklin (5) has described the various illegalities of the Jewish and Roman trials.)

\section{Health of Jesus}

The rigors of Jesus' ministry (that is, traveling by foot throughout Palestine) would have precluded any major physical illness or a weak general constitution. Accordingly, it is reasonable to assume that Jesus was in good physical condition before his walk to Gethsemane. However, during the 12 hours between 9 PM Thursday and 9 AM Friday, he had suffered great emotional stress (as evidenced by hematidrosis), abandonment by his closest friends (the disciples), and a physical beating (after the first Jewish trial). Also, in the setting of a traumatic and sleepless night, had been forced to walk more than 2.5 miles $(4.0 \mathrm{~km})$ to and from the sites of the various trials. These physical and emotional factors may have rendered Jesus particularly vulnerable to the adverse hemodynamic effects of the scourging.

\section{SCOURGING}

\section{Scourging Practices}

Flogging was a legal preliminary to every Roman execution, (28) and only women and Roman senators or soldiers (except in cases of desertion) were exempt. (11) The usual instrument was a short whip (flagrum or flagellum) with several single or braided leather thongs of variable lengths, in which small iron balls or sharp pieces of sheep bones were tied at intervals. Occasionally, staves also were used. $(8,12)$ For scourging, the man was stripped of his clothing, and his hands were tied to an upright post. (11)

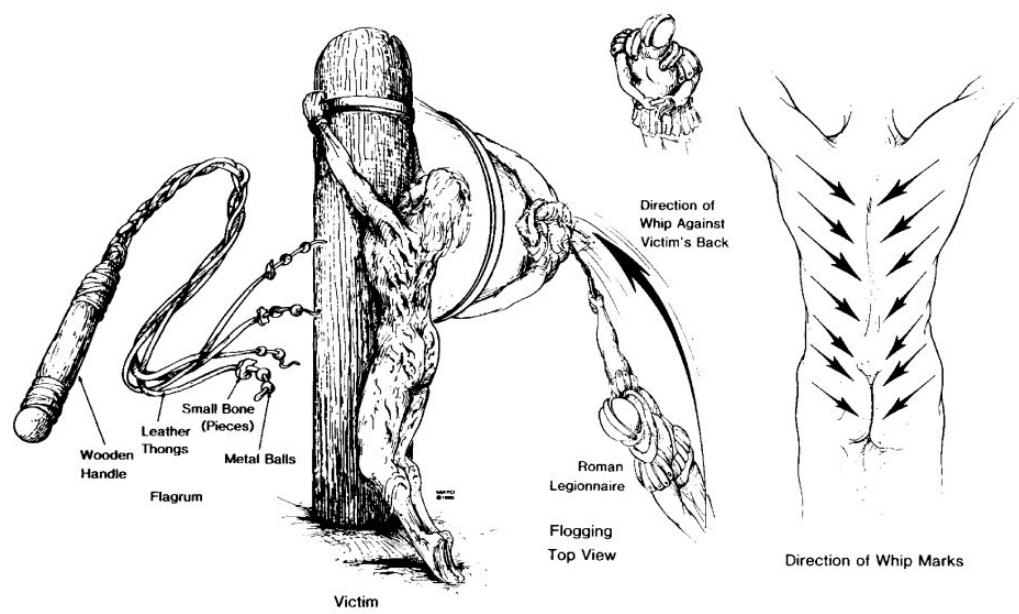
The back, buttocks, and legs were flogged either by two soldiers (lictors) or by one who alternated positions. $(5,7,11,28)$ The severity of the scourging depended on the disposition of the lictors and was intended to weaken the victim to a state just short of collapse or death. (8) After the scourging, the soldiers often taunted their victim. (11)

\section{Medical Aspects of Scourging}

As the Roman soldiers repeatedly struck the victim's back with full force, the iron balls would cause deep contusions, and the leather thongs and sheep bones would cut into the skin and subcutaneous tissues. (7) Then, as the flogging continued, the lacerations would tear into the underlying skeletal muscles and produce quivering ribbons of bleeding flesh. $(27,25)$ Pain and blood loss generally set the stage for circulatory shock. (12) The extent of blood loss may well have determined how long the victim would survive on the cross. (3) 
At the Praetorium, Jesus was severely whipped. (Although the severity of the scourging is not discussed in the four gospel accounts, it is implied in one of the epistles (1 Peter 2:24). A detailed word study of the ancient Greek text for this verse indicates that the scourging of Jesus was particularly harsh. (33) ) It is not known whether the number of lashes was limited to 39, in accordance with Jewish law. (5) The Roman soldiers, amused that this weakened man had claimed to be a king, began to mock him by placing a robe on his shoulders, a crown of thorns on his head, and a wooden staff as a scepter in his right hand. (1) Next, they spat on Jesus and struck him on the head with the wooden staff. (1) Moreover, when the soldiers tore the robe from Jesus' back, they probably reopened the scourging wounds. (7)

The severe scourging, with its intense pain and appreciable blood loss, most probably left Jesus in a preshock state. Moreover, hematidrosis had rendered his skin particularly tender. The physical and mental abuse meted out by the Jews and the Romans, as well as the lack of food, water, and sleep, also contributed to his generally weakened state. Therefore, even before the actual crucifixion, Jesus' physical condition was at least serious and possibly critical.

\section{CRUCIFIXION}

\section{Crucifixion Practices}

Crucifixion probably first began among the Persians. (34) Alexander the Great introduced the practice to Egypt and Carthage, and the Romans appear to have learned of it from the Carthaginans. (11) Although the Romans did not invent crucifixion, they perfected it as a form of torture and capital punishment that was designed to produce a slow

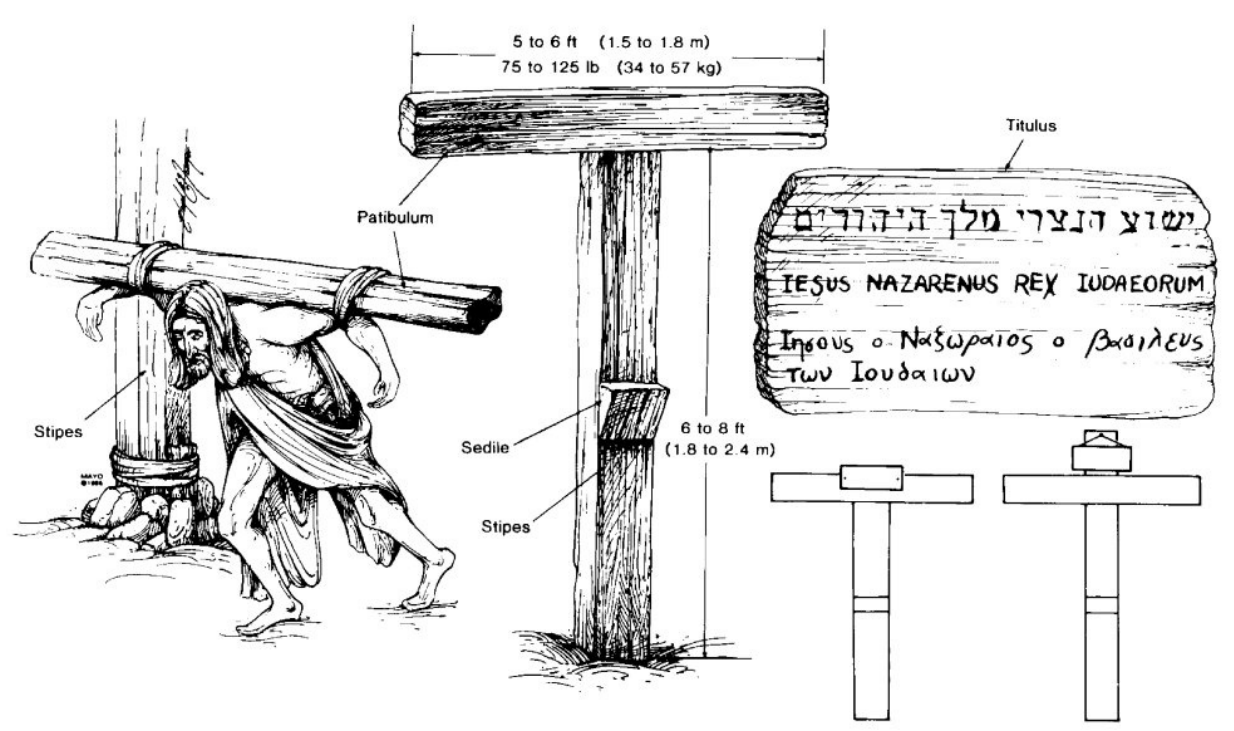
death with maximum pain and suffering. $(10,17)$ It was one of the most disgraceful and cruel methods of execution and usually was reserved only for slaves, foreigners, revolutionaries, and the vilest of criminals. $(3,25,28)$ Roman law usually protected Roman citizens from crucifixion, (5) except perhaps in the case of desertion by soldiers.

In its earliest form in Persia, the victim was either tied to a tree or was tied to or impaled on an upright post, usually to keep the guilty victim's feet from touching holy ground. $(3,11,30,34,38)$. Only later was a true cross used; it was characterized by an upright post (stipes) and a horizontal crossbar (patibulum), and it had several variations (11). Although archaeological and historical evidence strongly indicates that the low Tau cross was preferred by the Romans in Palestine at the time of Christ, $(2,7,11)$ crucifixion practices often varied in a given geographic region and in accordance with the imagination of the executioners, and the Latin cross and other forms also may have been used. (26)

It was customary for the condemned man to carry his own cross from the flogging post to the site of crucifixion outside the city walls. $(8,11,30) \mathrm{He}$ was usually naked, unless this was prohibited by local customs. (11) Since the weight of the entire cross was probably well over $300 \mathrm{lb}$. (136 kg), only the crossbar was carried. (11) The patibulum, weighing 75 to $125 \mathrm{lb}$. (34 to $57 \mathrm{~kg}),(11,30)$ was placed across the nape of the victim's neck and balanced along both shoulders. Usually, the outstretched arms then were tied to the crossbar. $(7,11)$ The processional to the site of crucifixion was led by a complete Roman military guard, headed by a centurion. $(3,11)$ One of the soldiers carried a sign (titulus) on which the condemned man's name and crime were displayed. $(3,11)$ Later, the titulus would be attached to the top of the cross. (11) The Roman guard would not leave the victim until they were sure of his death. $(9,11)$ 
Outside the city walls was permanently located the heavy upright wooden stipes, on which the patibulum would be secured. In the case of the Tau cross, this was accomplished by means of a mortise and tenon joint, with or without reinforcement by ropes. $(10,11,30)$ To prolong the crucifixion process, a horizontal wooden block or plank, serving as a crude seat (sedile or sedulum), often was attached midway down the stipes. $(3,11,16)$ Only very rarely, and probably later than the time of Christ, was an additional block (suppedaneum) employed for transfixion of the feet. $(9,11)$

At the site of execution, by law, the victim was given a bitter drink of wine mixed with myrrh (gall) as a mild analgesic. $(7,17)$ The criminal was then thrown to the ground on his back, with his arms outstretched along the patibulum. (11) the hands could be nailed or tied to the crossbar, but nailing apparently was preferred by the Romans. $(8,11)$ The archaeological remains of a crucified body, found in an ossuary near Jerusalem and dating from the time of Christ, indicate that the nails were tapered iron spikes approximately 5 to 7 in $(13$ to $18 \mathrm{~cm})$ long with a square shaft $3 / 8$ in $(1 \mathrm{~cm})$ across. $(23,24,30)$ Furthermore, ossuary findings and the Shroud of Turin have documented that the nails commonly were driven through the wrists rather than the palms. $(22-24,30)$

After both arms were fixed to the crossbar, the patibulum and the victim, together, were lifted onto the stipes. (11) On the low cross, four soldiers could accomplish this relatively easily. However, on the tall cross, the soldiers used either wooden forks or ladders. (11)

Next, the feet were fixed to the cross, either by nails or ropes. Ossuary findings and the Shroud of Turin suggest that nailing was the preferred Roman practice. $(23,24,30)$ Although the feet could be fixed to the sides of the stipes or to a wooden footrest (suppedaneum), they usually were nailed directly to the front of the stipes. (11) To accomplish this, flexion of the knees may have been quite prominent, and the bent legs may have been rotated laterally $(23-25,30)$

When the nailing was completed, the titulus was attached to the cross, by nails or cords, just above the victim's head. (11) The soldiers and the civilian crowd often taunted and jeered the condemned man, and the soldiers customarily divided up his clothes among themselves. $(11,25)$ The length of survival generally ranged from three or four hours to three or four days and appears to have been inversely related to the severity of the scourging. $(3,11)$ However, even if the scourging had been relatively mild, the Roman soldiers could hasten death by breaking the legs below the knees (crurifragium or skelokopia). $(3,11)$

Not uncommonly, insects would light upon or burrow into the open wounds or the eyes, ears, and nose of the dying and helpless victim, and birds of prey would tear at these sites. (16) Moreover, it was customary to leave the corpse on the cross to be devoured by predatory animals. $(3,11,12,28)$ However, by Roman law, the family of the condemned could take the body for burial, after obtaining permission from the Roman judge. (11)

Since no one was intended to survive crucifixion, the body was not released to the family until the soldiers were sure that the victim was dead. By custom, one of the Roman guards would pierce the body with a sword or lance. $(3,11)$ Traditionally, this had been considered a spear wound to the heart through the right side of the chest -- a fatal wound probably taught to most Roman soldiers. (11) The Shroud of Turin documents this form of injury. $(5,11,22)$ Moreover, the standard infantry spear, which was 5 to $6 \mathrm{ft}(1.5$ to $1.8 \mathrm{~m}$ ) long (30) could easily have reached the chest of a man crucified on the customary low cross. (11)

\section{Medical Aspects of Crucifixion}

With a knowledge of both anatomy and ancient crucifixion practices, one may reconstruct the probably medical aspects of this form of slow execution. Each wound apparently was intended to produce intense agony, and the contributing causes of death were numerous.

The scourging prior to crucifixion served to weaken the condemned man and, if blood loss was considerable, to produce orthostatic hypotension and even hypovolemic shock. $(8,12)$ When the victim was thrown to the ground on his back, in preparation for transfixion of his hands, his scourging wounds most likely would become torn open again and contaminated with dirt. $(2,14)$ Furthermore, with each respiration, the painful 
scourging wounds would be scraped against the rough wood of the stipes. (7) As a result, blood loss from the back probably would continue throughout the crucifixion ordeal.

With arms outstretched but not taut, the wrists were nailed to the patibulum. $(7,11)$ It has been shown that the ligaments and bones of the wrist can support the weight of a body hanging from them, but the palms cannot. (11) Accordingly, the iron spikes probably were driven between the radius and the carpals or between the two rows of carpal bones, $(2,10,11,30)$ either proximal to or through the strong

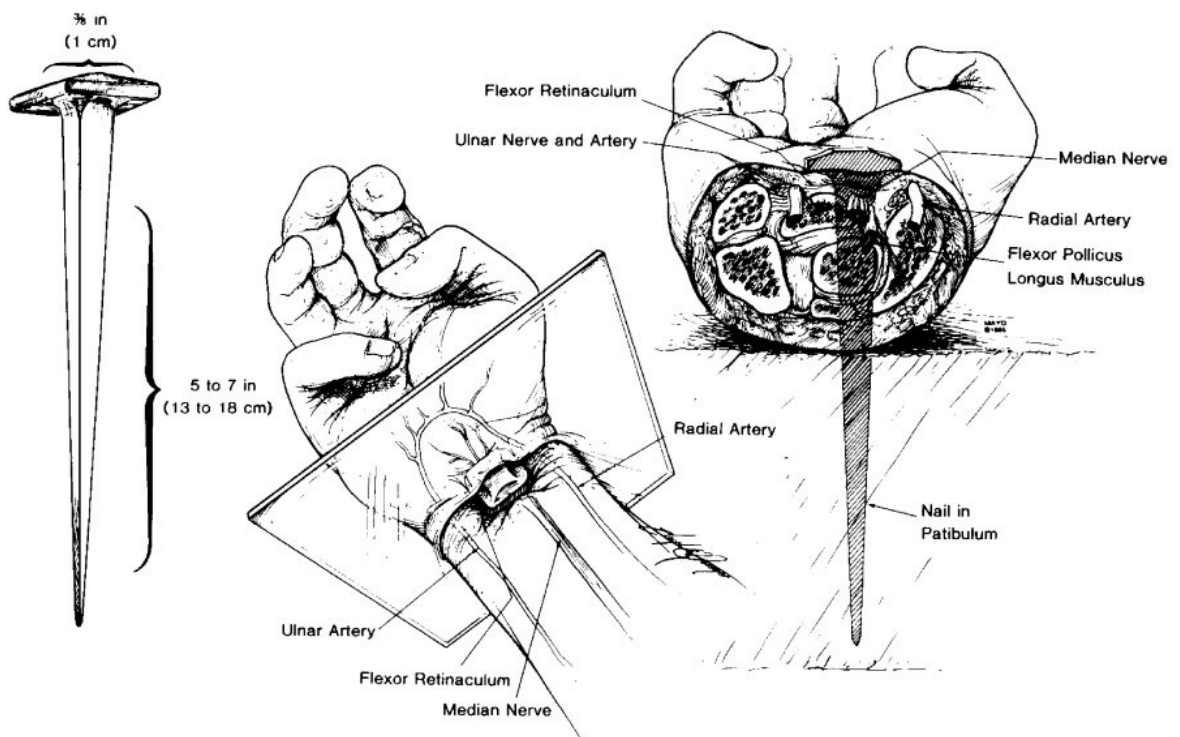
bandlike flexor retinaculum and the various intercarpal ligaments. Although a nail in either location in the wrist might pass between the bony elements and thereby produce no fractures, the likelihood of painful periosteal injury would seem great. Furthermore, the driven nail would crush or sever the rather large sensorimotor median nerve. $(2,7,11)$ The stimulated nerve would produce excruciating bolts of fiery pain in both arms. $(7,9)$ Although the severed median nerve would result in paralysis of a portion of the hand, ischemic contractures and impalement of various ligaments by the iron spike might produce a clawlike grasp.

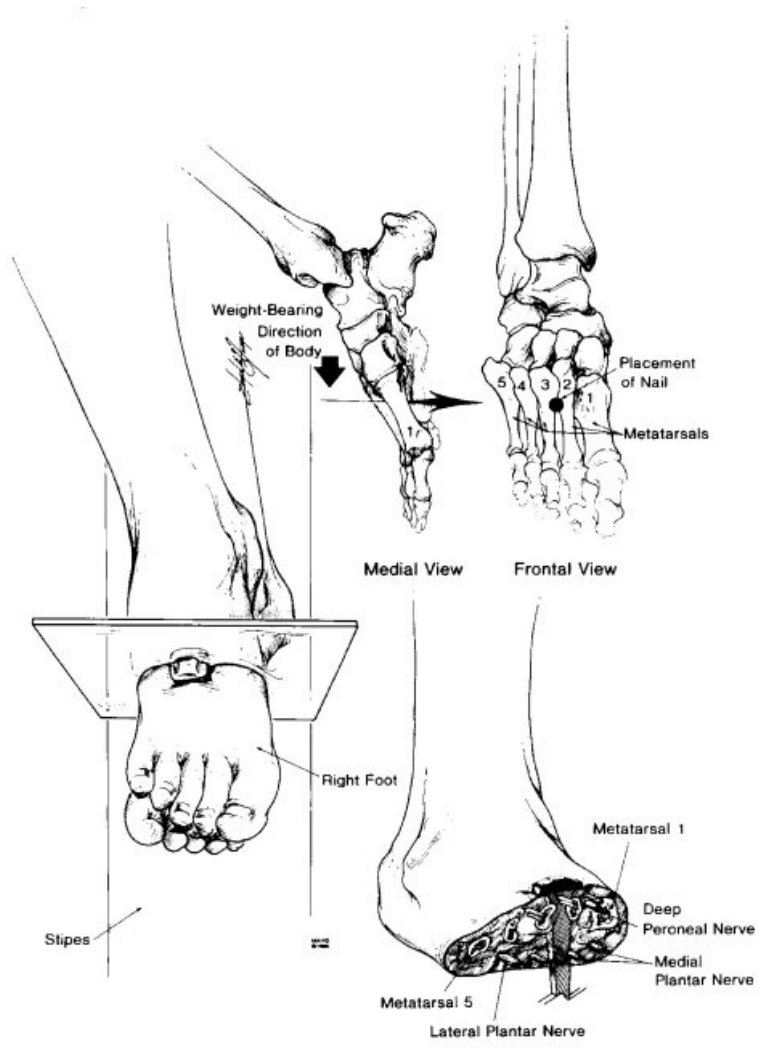

Most commonly, the feet were fixed to the front of the stipes by means of an iron spike driven through the first or second intermetatarsal space, just distal to the tarsometatarssal joint. $(2,5,8,11,30)$ It is likely that the deep peroneal nerve and branches of the medial and lateral plantar nerves would have been injured by the nails. Although scourging may have resulted in considerable blood loss, crucifixion per se was a relatively bloodless procedure, since no major arteries, other than perhaps the deep plantar arch, pass through the favored anatomic sites of transfixion. $(2,10,11)$

The major pathophysiologic effect of crucifixion, beyond the excruciating pain, was a marked interference with normal respiration, particularly exhalation. The weight of the body, pulling down on the outstretched arms and shoulders, would tend to fix the intercostal muscles in an inhalation state and thereby hinder passive exhalation. $(2,10,11)$ Accordingly, exhalation was primarily diaphragmatic, and breathing was shallow. It is likely that this form of respiration would not suffice and that hypercarbia would soon result. The onset of muscle cramps or tetanic contractions, due to fatigue and hypercarbia, would hinder respiration even further. (11)

Adequate exhalation required lifting the body by pushing up on the feet and by flexing the elbows and adducting the shoulders. (2) However, this maneuver would place the entire weight of the body on the tarsals and would produce searing pain. (7) Furthermore, flexion of the elbows would cause rotation of the wrists about the iron nails and cause fiery pain along the damaged median nerves. (7) Lifting of the body would also painfully scrape the scourged back against the rough wooden stipes. $(2,7)$ Muscle cramps 
and paresthesias of the outstretched and uplifted arms would add to the discomfort. (7) As a result, each respiratory effort would become agonizing and tiring and lead eventually to asphyxia. $(2,3,7,10)$

The actual cause of death by crucifixion was multifactorial and varied somewhat with each case, but the two most prominent causes probably were hypovolemic shock and exhaustion asphyxia. $(2,3,7,10)$ Other possible contributing factors included dehydration, $(7,16)$ stress-induced arrhythmias, $(3)$ and congestive heart failure with the rapid accumulation of pericardial and perhaps pleural effusions. $(2,7,11)$ Crucifracture (breaking the legs below the knees), if performed, led to an asphyxic death within minutes. (11) Death by crucifixion was, in every sense of the word, excruciating (Latin, excruciatus, or "out of the cross").

\section{Crucifixion of Jesus}

After the scourging and the mocking, at about 9 AM, the Roman soldiers put Jesus' clothes back on him and then led him and two thieves to be crucified. (1) Jesus apparently was so weakened by the severe flogging that he could not carry the patibulum from the Praetorium to the site of the crucifixion one third of a mile (600 to $650 \mathrm{~m}$ ) away $(1,3,5,7)$ Simon of Cyrene was summoned to carry Christ's cross, and the processional then made its way to Golgotha (or Calvary), an established crucifixion site.

Here, Jesus' clothes, except for a linen loincloth, again were removed, thereby probably reopening the scourging wounds. He then was offered a drink of wine mixed with myrrh (gall) but, after tasting it, refused the drink. (1) Finally, Jesus and the two thieves were crucified. Although scriptural references are made to nails in the hands (1), these are not at odds with the archaeological evidence of wrist wounds, since the ancients customarily considered the wrist to be a part of the hand. $(7,11)$ The titulus was attached above Jesus' head. It is unclear whether Jesus was crucified on the Tau cross or the Latin cross; archaeological findings favor the former (11) and early tradition the latter. (38) The fact that Jesus later was offered a drink of wine vinegar from a sponge placed on the stalk of the hyssop plant (1) (approximately $20 \mathrm{in}$, or $50 \mathrm{~cm}$ long) strongly supports the belief that Jesus was crucified on the short cross.

The soldiers and the civilian crowd taunted Jesus throughout the crucifixion ordeal, and the soldiers cast lots for his clothing. (1) Christ spoke seven times from the cross. (1) Since speech occurs during exhalation, these short, terse utterances must have been particularly difficult and painful. At about 3 PM that Friday, Jesus cried out in a loud voice, bowed his head, and died. (1) The Roman soldiers and onlookers recognized his moment of death. (1)

Since the Jews did not want the bodies to remain on the crosses after sunset, the beginning of the Sabbath, they asked Pontius Pilate to order crucifracture to hasten the deaths of the three crucified men. (1) The soldiers broke the legs of the two thieves, but when they came to Jesus and saw that he was already dead, they did not break his legs. (1) Rather, one of the soldiers pierced his side, probably with an infantry spear, and produced a sudden flow of blood and water. (1) Later that day, Jesus' body was taken down from the cross and placed in a tomb. (1) 


\section{DEATH OF JESUS}

Two aspects of Jesus' death have been the source of great controversy, namely, the nature of the wound in his side $(4,6)$ and the cause of his death after only several hours on the cross. (13-17).

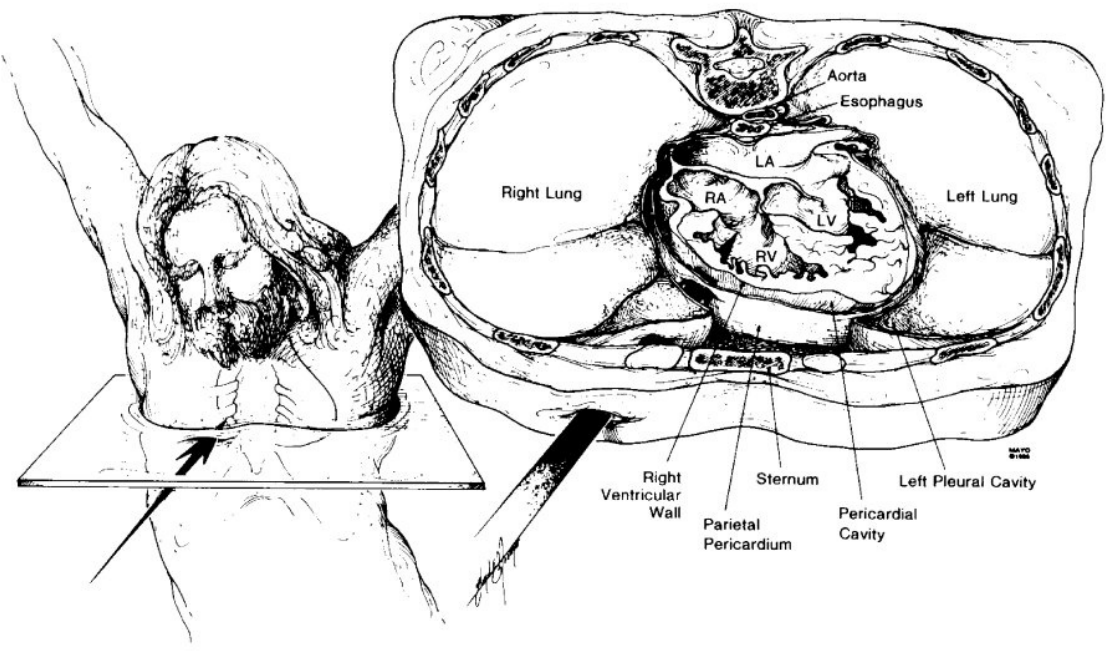

The gospel of John describes the piercing of Jesus' side and emphasizes the sudden flow of blood and water. (1) Some authors have interpreted the flow of water to be ascites (12) or urine, from an abdominal midline perforation of the bladder. (15) However, the Greek word (pleura $(32,35,36)$ used by John clearly denoted laterality and often implied the ribs. $(6,32,36)$

Therefore, it seems probable that the wound was in the thorax and well away from the abdominal midline.

Although the side of the wound was not designated by John, it traditionally has been depicted on the right side. (4) Supporting this traditions is the fact that a large flow of blood would be more likely with a perforation of the distended and thin-walled right atrium or ventricle than the thick-walled and contracted left ventricle. Although the side of the wound may never be established with certainty, the right seems more probable than the left.

Some of the skepticism in accepting John's description has arisen from the difficulty in explaining, with medical accuracy, the flow of both blood and water. Part of this difficulty has been based on the assumption that the blood appeared first, then the water. However, in the ancient Greek, the order of words generally denoted prominence and not necessarily a time sequence. (37) Therefore, it seems likely that John was emphasizing the prominence of blood rather than its appearance preceding the water.

Therefore, the water probably represented serous pleural and pericardial fluid, $(5-7,11)$ and would have preceded the flow of blood and been smaller in volume than the blood. Perhaps in the setting of hypovolemia and impending acute heart failure, pleural and pericardial effusions may have developed and would have added to the volume of apparent water. $(5,11)$ The blood, in contrast, may have originated from the right atrium or the right ventricle or perhaps from a hemopericardium. $(5,7,11)$

Jesus' death after only three to six hours on the cross surprised even Pontius Pilate. (1) The fact that Jesus cried out in a loud voice and then bowed his head and died suggests the possibility of a catastrophic terminal event. One popular explanation has been that Jesus died of cardiac rupture. In the setting of the scourging and crucifixion, with associated hypovolemia, hypoxemia, and perhaps and altered coagulable state, friable non-infective thrombotic vegetations could have formed on the aortic or mitral valve. These then could have dislodged and embolized into the coronary circulation and thereby produced an acute transmural myocardial infarction. Thrombotic valvular vegetations have been reported to develop under analogous acute traumatic conditions. (39) Rupture of the left ventricular free wall may occur, though uncommonly, in the first few hours following infarction. (40)

However, another explanation may be more likely. Jesus' death may have been hastened simply by his state of exhaustion and by the severity of the scourging, with its resultant blood loss and preshock state. (7) The fact that he could not carry his patibulum supports this interpretation. The actual cause of Jesus' death, like that of other crucified victims, may have been multifactorial and related primarily to hypovolemic shock, exhaustion asphyxia, and perhaps acute heart failure. $(2,3,5-7,10,11)$ A fatal cardiac arrhythmia may have 
accounted for the apparent catastrophic terminal event.

Thus, it remains unsettled whether Jesus died of cardiac rupture or of cardiorespiratory failure. However, the important feature may be not how he died but rather whether he died. Clearly, the weight of historical and medical evidence indicates that Jesus was dead before the wound to his side was inflicted and supports the traditional view that the spear, thrust between his right ribs, probably perforated not only the right lung but also the pericardium and heart and thereby ensured his death. Accordingly, interpretations based on the assumption that Jesus did not die on the cross appear to be at odds with modern medical knowledge.

\section{REFERENCES}

1. Matthew 26:17-27:61, Mark 14:12-15:47, Luke 22:7-23:56, John 13:1-19:42, the "The Holy Bible" (New International Version). Grand Rapids, Mich. Zondervan Bible Publishers, 1978.

2. Lumpkin R: The physical suffering of Christ. “J Med Assoc Ala” 1978;47:8-10,47.

3. Johnson CD: Medical and cardiological aspects of the passion and crucifixion of Jesus, the Christ. "Bol Assoc Med PR” 1978;70:97-102.

4. Barb AA: The wound in Christ's side. "J Warbury Courtauld Inst” 1971;34:320-321.

5. Bucklin R: The legal and medical aspects of the trial and death of Christ. "Sci Law" 1970; 10:14-26.

6. Mikulicz-Radecki FV: The chest wound in the crucified Christ. "Med News" 1966;14:30-40.

7. Davis CT: The crucifixion of Jesus: The passion of Christ from a medical point of view. "Ariz Med" $1965 ; 22: 183-187$.

8. Tenney SM: On death by crucifixion. “Am Heart J” 1964;68:286-287.

9. Bloomquist ER: A doctor looks at crucifixion. "Christian Herald”, March 1964, pp 35 46-48.

10. DePasquale NP, Burch GE: Death by crucifixion. “Am Heart J” 1963;6:434-435.

11. Barbet P: "A Doctor at Calvary: The Passion of Our Lord Jesus Christ as Described by a Surgeon", Earl of Wicklow (trans). Garden City, NY, Doubleday Image Books, 1953, pp 12-18, 37-147, 159-175, 187-208.

12. Primrose WB: A surgeon looks at the crucifixion. "Hibbert J" 1949, pp 382-388.

13. Bergsma S: did Jesus die of a broken heart? "Calvin Forum” 1948;14:163-167.

14. Whitaker JR: The physical cause of the death of our Lord. "Cath Manchester Guard" 1937;15:83-91.

15. Clark CCP: What was the physical cause of the death of Jesus Christ? "Med Rec" 1890; 38:543.

16. Cooper HC: The agony of death by crucifixion. "NY Med J" 1883:38:150-153.

17. Shroud W: "Treatise on the Physical Cause of the Death of Christ and Its Relation to the Principles and Practice of Christianity" ed 2. London, Hamilton \& Adams, 1871, pp 28-156, 489-494.

18. Allen AC: “The Skin: A Clinicopathological Treatise", ed 2. New York, Grune \& Stratton Inc, 1967, pp 745-747.

19. Sutton RL Jr: “Diseases of the Skin”, ed 11. St Louis, CV Mosby Co, 1956, pp 1393-1394.

20. Scott CT: A case of haematidrosis. "Br Med J" 1918;1:532-533.

21. Klauder JV: Stigmatization. “Arch Dermatol Syphilol” 1938;37:650-659.

22. Weaver KF: The mystery of the shroud. "Natl Geogr" 1980;157:730-753. 
23. Tzaferis V: Jewish tombs at and near Giv'at ha-Mivtar, Jerusalem. “Israel Explor J” 1970;20:38-59.

24. Haas N: Anthropological observations on the skeletal remains from Giv'at ha-Mivtar. "Israel Explor J" 1970;20:38-59.

25. McDowell J: “The Resurrection Factor” San Bernardino, Calif, Here's Life Publishers, 1981, pp 20-53, 75-103.

26. McDowell J: "Evidence That Demands a Verdict: Historical Evidence for the Christian Faith." San Bernardino, Calif, Here's Life Publishers, 1979, pp 39-87, 141-263.

27. McDowell J: "More Than a Carpenter" Wheaton, Ill, Tyndale House Publishers, 1977, pp 36-71, 89-100.

28. Hengel M: "Crucifixion in the Ancient World and the folly of the Message of the Cross" Bowden J (trans) Philadelphia, Fortress Press, 1977, pp 22-45, 86-90.

29. Ricciotti G: "The Life of Christ" Zizzamia AI (trans). Milwaukee, Bruce Publishing Co, 1947, pp 29-57, 78-153, 161-167, 586-647.

30. Pfeiffer CF, Vos HF, Rea J (eda): "Wycliffe Bible Encyclopedia." Chicago Moody Press, 1975, pp 149$152,404-405,713-723,1173,1174,150-1523$.

31. Greenleaf S: "An Examination of the Testimony of the four Evangelists by the Rules of Evidence Administered in the Courts of Justice." Grand Rapids, Mich, Baker Book House, 1965, p. 29.

32. Hatch E, Redpath HA: "A Concordance to the Septuagint and the Other Greek Versions of the Old Testament (Including the Apocryphal Books) Graz, Austria, Akademische Druce U Verlagsanstalt, 1975, p 1142.

33. Wuest KS: "Wuest Word Studies From the Greek New Testament for the English Reader." Grand Rapids, Mich. WB Eerdmans Publisher, 1973, vol 1, p 280.

34. Friedrich G: "Theological Dictionary of the New Testament", Bremiley G (ed-trans). Grand Rapids, Mich. WB Eerdmans Publisher, 1971, vol 7, pp 572,573,632.

35. Aradt WF, Gingrich FW: "A Greek-English Lexicon of the New Testament and Other Early Christian Literature." University of Chicago Press, 1057, p 673.

36. Brown F, Driver SR, Briggs CA: "A Hebrew and English Lexicon of the Old Testament With an Appendix Containing the Biblical Aramaic.” Oxford, England, Clarendon Press, 1953, pp 841, 854.

37. Robertson AT: "A Grammar of the Greek New Testament in Light of Historical Research." Nashville, Tenn, Broadman Press, 1931, pp 417-427.

38. Jackson SM (ed): “The New Schaff-Herzog Encyclopedia of Religious Knowledge.” New York, Funk \& Wagnalls, 1909, pp 312-314.

39. Kim H-S, Suzuki M, Lie JT, et al: Nonbacterial thrombotic endocarditis (NBTE) and disseminated intravascular coagulation (DIC): Autopsy study of 36 patients. "Arch Pathol Lab Med” 1977;101:65-68.

40. Becker AE, van Mantgem J-P: Cardiac tamponade: A study of 50 hearts. "Eur J Cardiol” 1975;3:349358. 